\title{
THE METHODS ND MATERIALS FOR PROMOTING READING LITERACY SKILLS FOR 6 TO 7 YEAR OLD CHILDREN
}

\author{
Sarmīte Tubele \\ University of Latvia, Latvia \\ Kristīne Serova \\ University of Latvia, Latvia
}

\begin{abstract}
This article summarizes the methods and materials for promoting literacy skills for 6 to 7 year old children. It is essential to promote reading literacy as the ability to read is one of the basic needs in modern society. It has been proved that the ability to read is correlated with one's cognitive development, in particular with the ability to distinguish phonemes. These methods and materials are aimed at the improvement of the phonological awareness and they seek to raise a child's interest to read.

A total of 33 children, 12 parents, 5 teachers and 4 speech and language therapists participated in this study. The research included 26 training lessons. The purpose of this research was to evaluate the developed material as a reading literacy promotion tool for 6 to 7 year old children. The following research methods were used: the analysis of the scientific literature and the evaluation of the children's reading performance. During the research the following observation was made: the most significant improvement in the reading performance was demonstrated by the first grade children as compared to kindergarten children with a linear improvement results. When interpreting the results, the following aspects should be taken into consideration: a child's overall cognitive development, the school's curriculum and the child's environment.
\end{abstract}

Keywords: reading literacy for 6 to 7 year old children, phonological awareness, reading literacy improvement, methods and materials for reading literacy promotion.

\section{Introduction}

As long as we can date human history, every human being was eager to share his experiences with his fellows as well as to pass the acquired knowledge to the next generation. The language competency made this possible although the human race has never stopped looking for the ways to improve it. It is not surprising that humans created written form of language which in itself can be considered as one of the most important human 
inventions. The language takes the form of reading and writing (Lūse, Miltina \& Tūbele, 2012). At the very beginning of writing only the author could read his own writing (Šēnveilers \& Ptoks 2001) because there existed no system for symbols and its use. During the technological age the literacy skills are becoming even more important (Riley, 2001). The literacy skills are now one of the basic human needs (Moterri \& Frandell, 2013), even more so - literacy is the very basic skill that is an obligatory prerequisite for inclusion into the modern society (Carreiras, Armstrong \& Danubeita, 2018). Literacy is the most important part of the formal education (Chou, Cheng \& Cheng, 2016), and not only the ability to read and write by itself, but more so the skill to select useful, necessary and true information for a particular purpose (Anspoka \& Tūbele, 2015). A person's literacy skills serve as a clear indicator of his quality of life.

The development of language comprises of several essential stages. We can assume that the foundations of literacy are laid at the age of seven month when a child starts to distinguish the phonemes of his or her native language. As opposed to a spoken language that a child can master simply by listening to speakers around him, literacy should be thought (Woolfolk, 2016) and it requires certain effort and abilities. It is considered that at the age of four a child becomes aware of the different symbols including letters. At this age he or she can be thought to recognize the letters as part of the language. One of the questions that teachers and parents are preoccupied with is how a child can acquire literacy skills as fast and simple as possible (Ptičkina, 1997). This question will be discussed in this article where different materials i.e. digital and paper are combined with scientifically proved methods.

\section{Theoretical Framework and Methodology}

In several countries including Latvia a child starts his formal education at the age of five. Nevertheless the main activity even at this age is the play as such that promotes maturity of social, cognitive and emotional areas (Woolfolk, 2016) and the play with loud talk helps the child to develop his language skills. At the age of six children begin to read and write as part of the play.

Usually one year after the formal education has begun, i.e., at the age of six, the possible learning difficulties or disorders in a child can be noticed. One of the commonly distributed disorder that is the basis for different learning difficulties as well as the difficulties in reading and writing, is the underdevelopment of the phonological processes (Tūbele, 2019). All the errors of a child's spoken language will be present in his reading and writing activity. 
Summarizing several authors (Carreras, Armstrong \& Danubeita 2018; Kaulin,a \& Tūbele, 2012; Lūse, Miltina \& Tūbele, 2012; Schleicher, 2019; Sternberg \& Sternberg, 2016; Tūbele, 2008; Tūbele \& Lūse, 2012; Woolfolk, 2016; Zmitričenoka, 2007) the reading skills can be defined as a child's ability to decode written symbols into words of language, understanding of these symbols, the reaction of speech to written text, the receptive communication, the tool of critical thinking, the decision making and lastly the acquisition of knowledge. The reading skills are closely related to a child's cognitive development.

It is important to emphasize that reading literacy is the skill that can be improved throughout one's life by improving the use and comprehension of a language (Tübele, 2008), and by increasing the vocabulary size. The following scientists have found that the reading literacy score at the first grade will determine reading literacy score in later grades (Gillion, 2017; Mullis, et al., 2017; Woolfolk, 2016). It is true that the basic skills for reading literacy should be built during the preschool years, and these skills include the knowledge about language, and techniques for text comprehension.

Different authors (Anspoka \& Tūbele, 2015; Ehri, 1992, as it is quoted Harley, 2001; Karule, 1997; Montesori, as it is quoted Ward, 2017; Ptičkina, 1997; Tūbele, 2008) split the process of learning to read into different stages. This overview can be seen in table 1 (see Table 1).

Table 1. Reading literacy development stages according to different authors

\begin{tabular}{|c|c|c|c|c|}
\hline $\begin{array}{l}\text { S. Tubele } \\
\text { (Tubele, } \\
\text { 2008) }\end{array}$ & $\begin{array}{l}\text { Z. Anspoka, } \\
\text { A. Karule } \\
\text { (Anspoka \& } \\
\text { Tūbele, 2015; } \\
\text { Karule, 1997) }\end{array}$ & $\begin{array}{l}\text { A. Ptickina } \\
\text { (Ptičkina, } \\
\text { 1997) }\end{array}$ & $\begin{array}{l}\text { L. C. Ehri } \\
\text { (Harley, 2001, 223) }\end{array}$ & $\begin{array}{l}\text { M. Montessori } \\
\text { (Ward, 2017) }\end{array}$ \\
\hline $\begin{array}{l}\text { Analytical } \\
\text { stage - basic } \\
\text { reading skills, } \\
\text { i.e., alphabet, } \\
\text { letter - } \\
\text { phoneme } \\
\text { pair, } \\
\text { phonological } \\
\text { awareness. }\end{array}$ & $\begin{array}{l}\text { Pre-alphabet } \\
\text { stage - } \\
\text { phonematic } \\
\text { notions, word } \\
\text { division into } \\
\text { syllables and } \\
\text { phonemes. } \\
\text { Development of } \\
\text { listening skills. }\end{array}$ & $\begin{array}{l}\text { First step - } \\
\text { precise } \\
\text { phoneme } \\
\text { pronunciation, } \\
\text { alphabet, } \\
\text { letter - } \\
\text { phoneme pair. }\end{array}$ & $\begin{array}{l}\text { Pre-alphabet phase - } \\
\text { very little knowledge } \\
\text { of letter - sound } \\
\text { correspondence; } \\
\text { reading by rote. }\end{array}$ & $\begin{array}{l}\text { First step - } \\
\text { introduction } \\
\text { into the world } \\
\text { of language - } \\
\text { stories, games } \\
\text { with sounds } \\
\text { and phonemes, } \\
\text { small books. }\end{array}$ \\
\hline $\begin{array}{l}\text { Analytic } \\
\text { synthesis } \\
\text { stage - } \\
\text { reading from } \\
\text { syllables to } \\
\text { words. }\end{array}$ & $\begin{array}{l}\text { Alphabet } \\
\text { stage - } \\
\text { understanding } \\
\text { of letter - } \\
\text { phoneme pair, } \\
\text { training of basic } \\
\text { mechanisms for } \\
\text { reading. }\end{array}$ & $\begin{array}{l}\text { Second } \\
\text { step - syllable } \\
\text { reading from } \\
\text { simplest to } \\
\text { hardest. }\end{array}$ & $\begin{array}{l}\text { Partial alphabet } \\
\text { phase - partial } \\
\text { knowledge of spel- } \\
\text { ling - pronunciation } \\
\text { correspondence, } \\
\text { but unable to } \\
\text { segment all } \\
\text { sounds in a word's } \\
\text { pronunciation. }\end{array}$ & $\begin{array}{l}\text { Second step - } \\
\text { word phoneme } \\
\text { analysis } \\
\text { with sound } \\
\text { reinforcement } \\
\text { method. }\end{array}$ \\
\hline
\end{tabular}




\begin{tabular}{|c|c|c|c|c|}
\hline $\begin{array}{l}\text { S. Tubele } \\
\text { (Tubele, } \\
\text { 2008) }\end{array}$ & $\begin{array}{l}\text { Z. Anspoka, } \\
\text { A. Karule } \\
\text { (Anspoka \& } \\
\text { Tūbele, 2015; } \\
\text { Karule, 1997) } \\
\end{array}$ & $\begin{array}{l}\text { A. Ptickina } \\
\text { (Ptičkina, } \\
\text { 1997) }\end{array}$ & $\begin{array}{l}\text { L. C. Ehri } \\
\text { (Harley, 2001, 223) }\end{array}$ & $\begin{array}{l}\text { M. Montessori } \\
\text { (Ward, 2017) }\end{array}$ \\
\hline \multirow[t]{2}{*}{$\begin{array}{l}\text { Synthesis } \\
\text { stage - } \\
\text { reading words } \\
\text { to word pairs. } \\
\text { Contextual } \\
\text { under- } \\
\text { standing. }\end{array}$} & $\begin{array}{l}\text { Post-alphabet } \\
\text { stage - training } \\
\text { for independent } \\
\text { work with text, } \\
\text { i.e., training of } \\
\text { word meanings, } \\
\text { speed reading } \\
\text { and awareness. }\end{array}$ & $\begin{array}{l}\text { Third step - } \\
\text { training of } \\
\text { word reading } \\
\text { skills - } \\
\text { synthesis of } \\
\text { syllables into } \\
\text { words. }\end{array}$ & $\begin{array}{l}\text { Alphabet phase - } \\
\text { complete connection } \\
\text { between letters and } \\
\text { sounds. }\end{array}$ & $\begin{array}{l}\text { Third step - } \\
\text { synthesis of } \\
\text { phonemes into } \\
\text { words with } \\
\text { the decoding } \\
\text { method. }\end{array}$ \\
\hline & & $\begin{array}{l}\text { Fourth step - } \\
\text { development } \\
\text { of reading } \\
\text { literacy using } \\
\text { different types } \\
\text { of literature. }\end{array}$ & $\begin{array}{l}\text { Consolidated } \\
\text { phase - reading like } \\
\text { an adult; can oper- } \\
\text { ate with multi-letter } \\
\text { units, e.g. syllables, } \\
\text { rimes, morphemes. }\end{array}$ & $\begin{array}{l}\text { Fourth step - } \\
\text { gradual aware- } \\
\text { ness of reading } \\
\text { literacy, } \\
\text { contextual un- } \\
\text { derstanding. }\end{array}$ \\
\hline
\end{tabular}

Although the number of steps and the expected skills differ for each author, they all agree that these steps are successive and cannot be omitted.

The authors of this research highlight three training areas of reading literacy development:

- Training for basic reading skills (phonological awareness, letters, letter - phoneme correspondence, analysis of words and syllables, synthesis of syllables and phonemes into words).

- Training for reading accuracy, precision and speed.

- Training for reading awareness and text comprehension.

The training material for teaching to read should be designed so that all three stages would occur simultaneously.

Several authors (Goswami \& Bryant 2016; Irbe \& Lindenberga, 2015; Karule, 1997; Ptičkina, 1997; Tūbele, 2019; Wagner,et al. 2019) state that training for gaining basic reading skills should include the following steps:

1) Analysis:

- simple compound words division into constructing words;

- words division into syllables;

- rhyming words;

- word division into rimes, onsets, first, last phonemes, etc;

2) Letters vs phonemes:

- teaching of letters;

- teaching letter - phoneme correspondence;

3) Synthesis:

- compound words construction;

- words construction from syllables;

- words construction from phonemes; 
4) Reading:

- words construction from phonemes and association with letters;

- reading of mono-syllable words consisting of two letters, reading of mono-syllables;

- reading of mono-syllables with different levels of difficulty;

- reading of two and later three syllable phonematically simple words;

- reading of two syllable words with consonant aggregation;

- strengthening word reading skills;

- reading of joint words;

- reading of sentences and text.

In order to teach the reading accuracy the most popular method is a word decoding method, but there also exist a method where a whole word is recognized. Rayner et al (Rayne, et al., 2012) states that it is faster to find a word in lexicon if a particular letter combination is familiar. Several authors (Eysenck \& Keane, 2015; Goswami \& Bryant 2016; Gillon, 2017; Sternberg \& Sternberg, 2016; Tūbele, 2008) mention such a thing as guessing from a context (parsing and priming effect) and guessing from visual similarities. Both these techniques increase the reading speed, but they require the language and reading experience to be used correctly. Tubele (Tūbele, 2008) states that the reading speed improves when a reader's saccade is at least five symbols, for skilled readers it is usually about nine symbols (Eysenck \& Keane, 2015; Rayne, et al. , 2012; Sternberg \& Sternberg, 2016), but it may vary depending on the language. Reading the syllables are important for remembering typical phoneme combinations, but reading the rhymes helps a reader to recognize various word parts that are different from each other. In order to store a typical letter combinations of words in one's lexicon, it is recommended to listen and read a word that is highlighted. During the first year of learning to read it is not recommended to use syntactic neighbours and joint words without context. To summarize, the authors of this article emphasize that the reading accuracy improves if a reader uses the decoding method, guessing from context and language semantics for unknown words. The reading speed improves by training to read.

By improving the decoding skills the comprehension of written text also improves (Goswami \& Bryant 2016; Woolfolk, 2016). Vocabulary is as important for text comprehension as is the knowledge about syntax of a language that constructs the context. It is believed that a reader can comprehend a text fully if he understands about $95 \%$ of the words (Sternberg \& Sternberg 2016). The following two statements are true: good readers have a extensive vocabulary and those who have a extensive vocabulary can become good readers (Fisher \& Frey, 2014). It is very important to keep in mind that the use of language is constructive, as even during the process 
of reading the meaning of the text is being constructed (Goodman, 2005) and changed from the context, previous experience and the current parsing process. It is proved that children with comprehension difficulties have problems accessing lexicon (Sternberg \& Sternberg, 2016). In order to help construct the context, the training material should include visual clues (e.g., pictures) and also include the material necessary to build a network of semantically linked words and strategies to memorize the context, i.e., key words, formulation of main idea, questions and discussions about the text, etc.

\section{Designed Material and Research Results}

Taking into account everything mentioned before, the authors of this article developed the training material where the several reading promotion methods have been summarized. The material is designed for children from 6 to 7 years of age and it includes mobile games and paper materials. It gives an opportunity to improve the reading skills as part of a play. The underlining principle used in this material is "from the simple to the complex". The training material includes the following tasks:

1) Compound word division into constructing words and vice versa.

2) Word division into syllables and word construction from syllables.

3) Syllable division into phonemes and syllable construction from phonemes, typical phoneme combinations.

4) Improvement of reading:

- phoneme synthesis and two phoneme syllable reading material;

- phonematically simple two syllable word reading material;

- phonematically simple three syllable word reading material;

- phonematically complex two syllable word reading material;

- monosyllable word and phonematically complex polysyllabic reading material.

5) Creation and reading of linked words, sentences and stories.

In order to promote comprehension there are pictures or pictograms used whenever it is possible. The words, sentences and stories are chosen according to the needs, interests and everyday situations that are familiar to six to seven year old children.

The research took place in two preschool and primary school groups. Prior to include children into training group, they were tested with specially designed examination material. Examination material included phoneme naming tasks, phoneme distinguishing task and word and non word reading tasks. After testing there were 33 children selected and included into the training group with the written agreement of their parents. All children in the research group had a phonological perception disorder. 
Their reading skill level was generally lower than that of their peers without phonological perception disorder. All the children were divided by chance into smaller groups. Groups were not the same at every session. Every training group had one training in a week lasting 30 to 40 minutes during the period of four months. During every training session the authors were in the position of a speech therapist and an observer. Every training session consisted of the tasks from the designed material that suited (was in the closest developmental zone) a child's current level of his reading skills. In every session the feedback from the children was gathered. Feedback included individual reading and/or writing task. Feedback results were used for planning next training.

In order to evaluate the progress of the reading literacy there were two types of evaluation materials prior and after training period. First - random naming of 66 capital and lowercase letters and second - letter chain and word chain test. Letter and word chain tests was performed only by those children that had seven years old, as it is required in test design. Letter naming task was done individually - every child named letter sequence and authors of this research measured naming errors and time. Letter and word chain test was done in small groups according to test requirements. After testing all the data (number of correctly named letters, number of errors and time) was gathered into a table and compared with previously gathered data individually and between all children that participated in the research training.

The next figures (see Figure 1, Figure 2, Figure 3, Figure 4) contains the results of the research data analysis. The name of the child in the figure is replaced by the first letter of his or her name and nearest second letter that makes unique two letter combination with child's first name first letter.

Figure 1 (see Figure 1) shows a letter naming speed for all 33 children before the training, in September, and after training, in December.

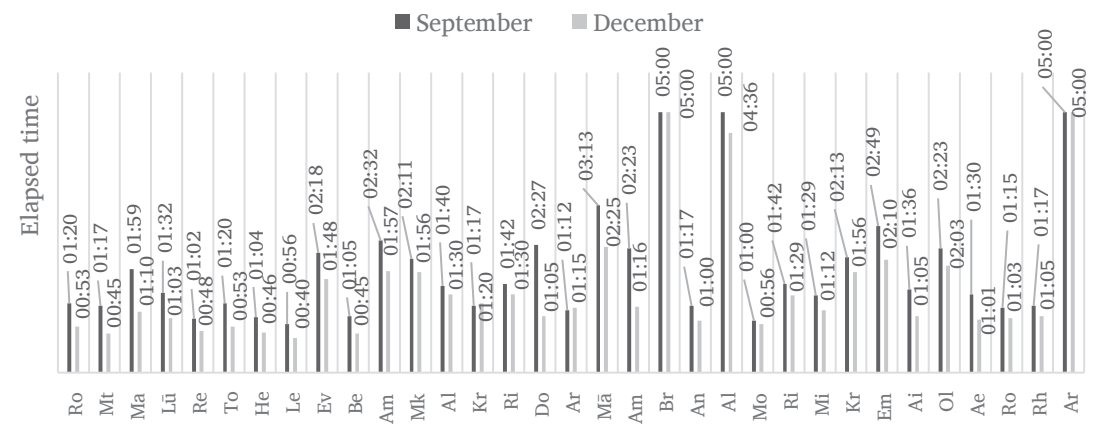

Figure 1. Letter naming speed before and after training 
As can be seen from figure 1, the letter naming time has decreased for almost all the children, i.e., all the children demonstrated an improved letter naming speed. Children who did not succeed in this task, also did not show any developmental progress in other cognitive areas outside the training.

Apart from measuring the time needed to name the letters, the authors also counted the number of letter naming errors. Figure 2 (see Figure 2) shows the number of wrongly named letters out of 66 given letters.

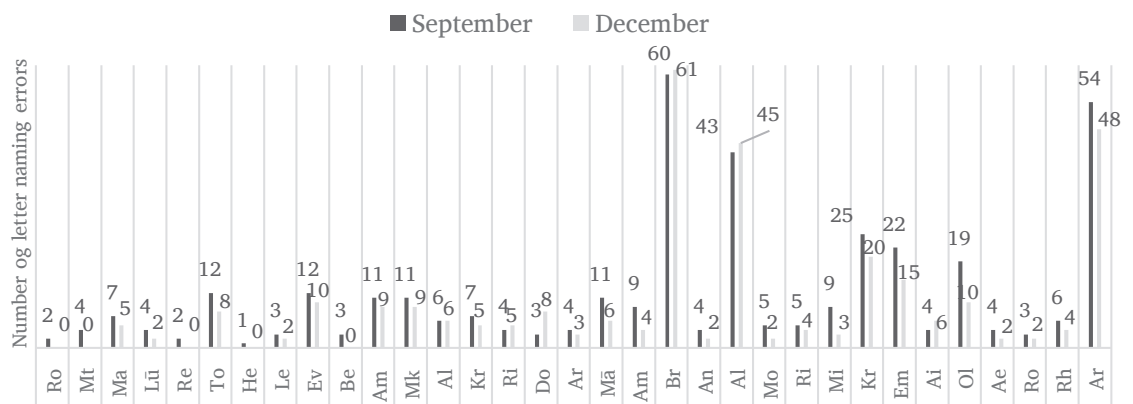

Figure 2. Errors during letter naming before and after training

Figure 2 shows a similar trend as figure 1 - almost all the children improved their letter naming skills, i.e., they demonstrated a decrease in the number of errors except for the children who did not show any developmental progress in other cognitive areas. Few children (e.g. "Do") mismatched Latvian letters with similar Russian letters at both evaluations, but these errors do not reflect a regress in the reading development.

Figure 3 shows the results of letter chain test before and after the training sessions (see Figure 3) In letter chain test participated only seven years old primary school children as it is required by test design.

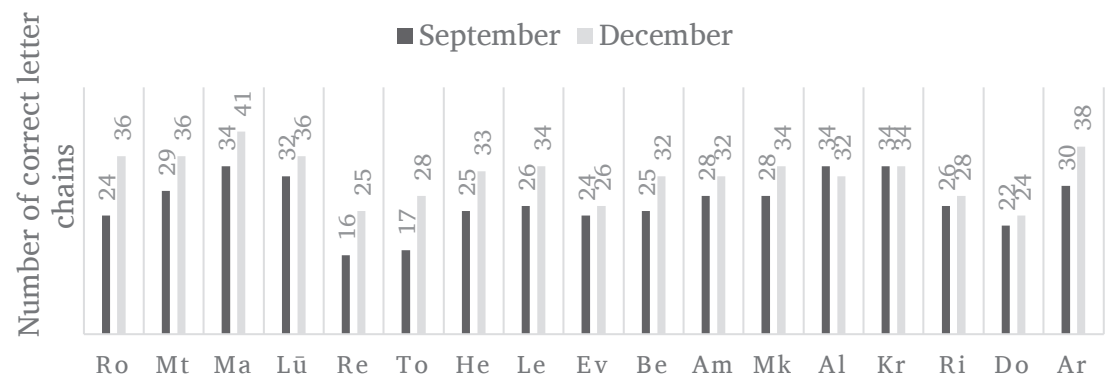

Figure 3. Result of letter chain test before and after evaluation 
In Figure 3 one can observe that all the children demonstrated smaller or larger progress in finding two similar upper case letters in any given letter sequence.

Figure 4 shows the results of word chain test before and after the training sessions (see Figure 4). In letter word test participated only seven years old primary school children as it is required by test design.

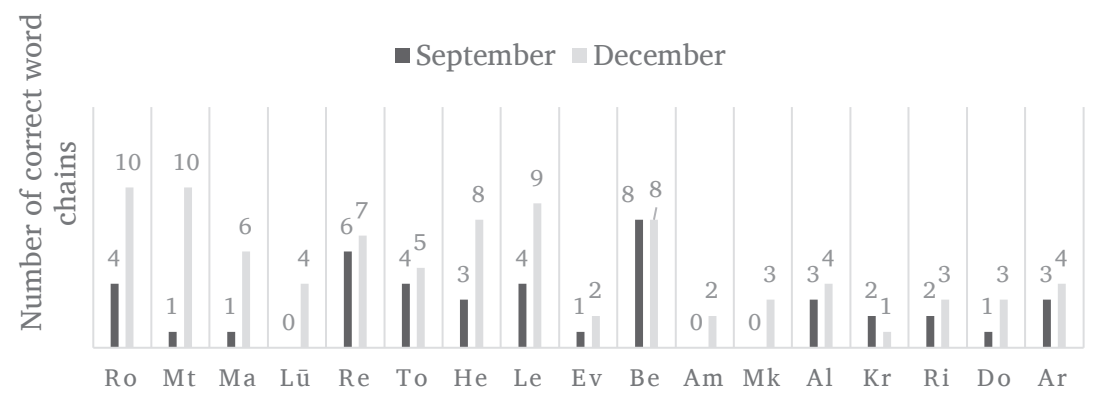

Figure 4. Result of word chain test before and after evaluation

In the author's view the word chain test represents real results of the reading literacy as a child has to select the words from a given word sequence without any spaces. As one can see from figure 4, almost all the children have improved their reading literacy, a higher improvement was for a child named "Mt". The authors could not indicate why a child named "Be" did not show any increase in the number of selected words, but this child showed progress in other evaluation tasks.

\section{Conclusions and Discussions}

The research proved the significance of systematically and methodologically correct training material that follows the steps of reading literacy development and child's learning and cognitive development. The highest reading literacy progress was demonstrated by the children of the first grade which is consistent with the findings of other researches mentioned in this article.

Decreased number of wrongly named letters might serve as proof that by training letter - phoneme correspondence and phoneme distinction children with the phonological perception disorder improved their reading accuracy.

Increased number of correctly read word chains after training might serve as proof that it is very important to include in the training tasks of typical syllable combination recognition, as it helps memorize typical phoneme combinations and increase reading speed. 
The children that showed very low or no improvement comparing the first and the last evaluation results, showed insignificant improvement in other areas of cognitive development as well.

One can discuss the different reading difficulties and disorders like dyslexia, whether it is possible to promote the reading literacy and if it is, whether this material will be designed well enough to become a suitable intervention tool in these difficulties and disorders.

\section{References}

Adams, J. M. (1994). Beginning to Read: Thinking and Learning about Print, UK: The MIT press.

Anspoka, Z. \& Tūbele, S. (2015). Lingvodidaktika latviešu valodā 1.-6. klasei [Lingvodidactics in Latvian language for $1^{\text {st }}-6^{\text {th }}$ grades]. Latvia: Latviešu valodas aǵentūra.

Carreras, M., Armstrong, B., C. \& Danubeita, J., A. (2018). Reading, Stevens' Handbook of Experimental Psychology and Cognitive Neuroscience $4^{\text {th }}$ edition, Vol. 3 Language and Thought. USA: Wiley.

Chou, M., Cheng, J. \& Cheng, Y. (2016). Operating Classroom Aesthetic Reading Environment to Raise Children's Reading Motivation, Universal Journal of Educational Research, 4(1), 81-97, doi: 10.13189/ujer.2016.040111.

Eysenck, M. W. \& Keane, M. T. (2015). Cognitive psychology a student's handbook. USA: Taylor \& Francis.

Fisher, D. \& Frey, N. (2014) Content Area Vocabulary Learning, The Reading Teacher, 68(8) 594-599, doi: 10.1002/trtr.1258.

Gillon, G. T. (2017). Phonological Awareness, Second Edition: From Research to Practice. USA: Guilford Publications.

Goodman, K. (2005). Making Sense of Written Language: A Lifelong Journey, Journal of literacy research, 37(1), doi: 10.1207/s15548430j1r3701_1.

Goswami, U. \& Bryant, P. (2016). Phonological skills and learning to read. USA: Routledge Taylor \& Francis group.

Harley, T. A. (2001) The psychology of language. USA: Psychology press.

Irbe, A. \& Lindenberga S. (2015). Bērns runāt mācās gómenē [Child learns to speak in the family]. Latvia: RaKa.

Karule, A. (1997). Ābeces mācibu metodika [Methodology of the alphabeth]. Latvia: Zvaigzne ABC.

Kauliņa, A. \& Tūbele, S. (2012). Lasǐšanas traucējumi [Reading Disorders]. Latvia: RaKa. Lightfoot, C., Cole, M. \& Cole, S. R. (2009). The Development of Children $6^{\text {th }}$ edition. USA: Worth Publishers.

Lūse, J., Miltina, I. \& Tūbele, S. (2012). Logopēdijas terminu skaidrojošā vārdnīca [Glossary of speech therapy terms]. Latvia: RaKa.

Moterri, G. A. S. \& Frandell, T. (2013). Literacy from a Right to Education Perspective. UNESCO. from https://unesdoc.unesco.org/ark:/48223/pf0000221427. 
Mullis, I. V. S., Martin, M. O., Foy, P. \& Hooper, M. (2017). International Results of Reading 2016. USA: IEA TIMSS \& PIRLS International Study Center.

Ptičkina, Ā. (1997). Kā mācīsim bērnus lasit un rakstit [How to teach children to read and write]. Latvia: Zvaigzne ABC.

Rayner, K., Pollatsek, A., Ashby, J. \& Clifton, Ch. (2012). Psychology of reading second edition, USA: Psychology press.

Riley, J. (2001). The National Literacy Strategy: success with literacy for all? Curriculum Journal, 12(1), 29-58, doi: 10.1080/09585170122654.

Schleicher, A. (2019). PISA 2018 Insights and Implementations, PISA, Paris: EOCD Publications.

Šēnveilers, R. \& Ptoks, M. (2001). Foniatrija un pedagoğiskā audioloğija [Phomiatry and pedagogical audiology]. Latvia: Apgāds Rasa "ABC".

Sternberg, R. J. \& Sternberg, K. (2016). Cognitive Psychology 7th edition, USA: Change Learning.

Tūbele, S. \& Lūse, J. (2012). Ja skolēns raksta nepareizi... [If a child writes incorrectly...]. Latvia: RaKa.

Tūbele, S. (2008). Disleksija vai lasišanas traucējumi [Dyslexia or Reading Disabilities]. Latvia: RaKa.

Tūbele, S. (2019). Valodas traucējumu novēršana [Evaluation of Language Disorders]. Latvia: RaKa.

Wagner, R. K., Joyner, R., Koh, P. W., Malkowski, A., Shenoy, S., Wood, S. G., Zhang, C. \& Zirps, F. (2019). Reading - Related phonological processing in English and Other Written Languages, Kilpatrick D. A. (eds.) Reading Development and Difficulties, Switzerland: Springer, doi: 10.1007/978-3-090-26550-2_2.

Ward, F. E. (2017). The Montessori Method and the American School. USA: Franclin Classics.

Woolfolk, A. (2016). Educational Psychology. $13^{\text {th }}$ edition. USA: Pearson.

Zmitričenoka, V. (2007). Lasīšanas traucējumi un to novēršana 5-6 gadus veciem bērniem ar VSNA III pakāpē logopēdiskajā grupā [Reading disabilities and prevention in 5-6 years old children with DLD in logopedic group]. From: Inovācijas skolotāja logopēda darbïba 3 . Izdevums [Innovations in the activity of speech therapists. $3^{\text {rd }}$ edition]. 146-245, Latvia: RTA. 